\title{
Fungicide Resistance in Botrytis cinerea Populations in California and its Influence on Control of Gray Mold on Stored Mandarin Fruit
}

\author{
S. Saito and C. L. Xiao, ${ }^{\dagger}$ USDA - Agricultural Research Service (USDA-ARS), San Joaquin Valley Agricultural Sciences Center, 9611 South \\ Riverbend Ave, Parlier, CA 93648
}

\begin{abstract}
Gray mold caused by Botrytis cinerea is an emerging postharvest disease affecting stored mandarin fruit in California. To develop effective control programs, fungicide sensitivities to four citrus postharvest fungicides were determined. One hundred $B$. cinerea isolates each in 2015 and 2016 were obtained from decayed fruit collected within packinghouses and tested for resistance to the fungicides. Sensitivity to azoxystrobin was examined based on the point mutation in the $c y t$ b gene using PCR, while resistance to fludioxonil, pyrimethanil, and thiabendazole was examined on fungicide-amended media. For azoxystrobin, 83 and $98 \%$ of the isolates were resistant in 2015 and 2016, respectively. For pyrimethanil, 71 and $93 \%$ were resistant in 2015 and 2016, respectively. For thiabendazole, 63 and 68\% were resistant in 2015 and 2016, respectively.

No fludioxonil resistance was detected in both years. Five fungicideresistant phenotypes were detected, and the most common phenotype was triple resistance to azoxystrobin, pyrimethanil, and thiabendazole, accounting for 59 and $65 \%$ in 2015 and 2016, respectively. Of the 200 B. cinerea isolates, $5,23.5$, and $62 \%$ were resistant to one, two, or three classes of fungicides, respectively. Inoculation tests were conducted to evaluate if the fungicides at label rates controlled various resistant phenotypes on fruit. Most fungicides failed to control gray mold on mandarin fruit inoculated with the respective fungicide resistant phenotypes. Our results suggest that alternative control methods need to be integrated into existing decay control programs to target this emerging disease on mandarin fruit.
\end{abstract}

California is the leading producer of fresh market citrus in the United States, accounting for $83 \%$ of the production in 2015 (USDA-NASS 2017). A most notable change in the fresh citrus market in recent years is the increase in consumption of mandarin fruit (Webber et al. 2014). In response to such high demands for "easy-to-peel" mandarin fruit, the total acreage of mandarins in California has tripled over the past 15 years with a production value in 2015 exceeding $\$ 600$ million (USDA-NASS 2017). Mandarins are now the second most important citrus commodity behind navel oranges in California.

As mandarin production increases, storing mandarin fruit at 4 to $8^{\circ} \mathrm{C}$ before packing has become a common practice to retain fruit quality and extend marketing opportunities. Extended storage, however, can increase the risk for development of postharvest fruit rot diseases. Previously, we conducted a survey at citrus packinghouses in 2015 and 2016 to investigate prevalence and incidence of postharvest diseases of mandarin fruit (Saito and Xiao 2017). During the two-year survey, we observed six major postharvest diseases. These major postharvest diseases were Alternaria rot caused by Alternaria spp., blue mold caused by Penicillium italicum, green mold caused by $P$. digitatum, sour rot caused primarily by Geotrichum citri-aurantii, gray mold caused by Botrytis spp., and Mucor rot caused primarily by Mucor piriformis (Saito and Xiao 2017). Although there was year-to-year variation in the prevalence and incidence of those postharvest diseases, one of the important findings from the survey was that gray mold was an emerging disease on mandarin fruit during storage (Saito and Xiao 2017).

${ }^{\dagger}$ Corresponding author: C. L. Xiao; E-mail: Chang-Lin.Xiao@ars.usda.gov

Funding: This research was funded in part by the California Citrus Research Board.

Disclaimer: Mention of trade names or commercial products in this article is solely for the purpose of providing specific information and does not imply recommendations or endorsement by the U.S. Department of Agriculture. USDA is an equal opportunity provider and employer.

Accepted for publication 20 June 2018.

This article is in the public domain and not copyrightable. It may be freely reprinted with customary crediting of the source. The American Phytopathological Society, 2018.
Botrytis spp. can cause pre- and postharvest diseases on a wide range of economically important crops, including blueberries, table grapes, pistachio, and stone fruit that are commonly grown in the Central Valley of California (Saito et al. 2016b; Smilanick et al. 2010). Although the presence of B. pseudocinerea and a new Botrytis species, $B$. californica, have been reported on blueberry in central California (Saito et al. 2014, 2016a), B. cinerea is the major species responsible for Botrytis diseases in these crops in the region. Control of diseases caused by $B$. cinerea has largely been dependent on the use of synthetic fungicides. However, $B$. cinerea is a high risk pathogen for the development of resistance to fungicides (Brent and Hollomon 1998). High frequencies of isolates resistant to one or multiple chemically unrelated fungicides have been reported in $B$. cinerea populations from many crops (De Miccolis Angelini et al. 2014; Saito et al. 2016b; Weber 2011; Zhao et al. 2010). Determination of fungicide-resistant phenotypes in the $B$. cinerea population is instrumental to the success of a fungicide-based control program for Botrytis diseases (Walker et al. 2013).

In California, control of citrus postharvest diseases has long targeted $P$. digitatum, $P$. italicum, and $G$. citri-aurantii as they are historically common postharvest diseases on the major citrus types (Holmes and Eckert 1999; Kanetis et al. 2008; Smilanick and Mansour 2007; Smilanick et al. 1997, 2008). Several fungicides are labeled for postharvest use to control green mold, blue mold, and sour rot on citrus in California, and management of fungicide resistance is an integral part of citrus postharvest disease control practices. However, before gray mold became an emerging disease on stored mandarin fruit in recent years in California, B. cinerea was not among the target pathogens in postharvest disease control programs for citrus. In order to develop postharvest disease control programs that are effective against not only historically important diseases such as green mold and sour rot, but also emerging diseases such as gray mold, information is needed as to whether isolates of $B$. cinerea from mandarins are resistant to the currently registered postharvest fungicides such as azoxystrobin, thiabendazole, fludioxonil, and pyrimethanil that are known to be effective against $B$. cinerea.

The objectives of the study were to (i) test fungicide resistance of $B$. cinerea obtained from mandarin fruit to four citrus postharvest fungicides and determine their fungicide-resistant phenotypes, and (ii) evaluate efficacy of postharvest fungicides in controlling $B$. cinerea isolates exhibiting different fungicide resistant phenotypes. 


\section{Materials and Methods}

Isolates of Botrytis cinerea. In our previous study, we conducted a survey to determine major postharvest diseases affecting mandarin fruit during storage, and the details of the study were described elsewhere (Saito and Xiao 2017). Briefly, decayed mandarin fruit were sampled from fruit packinghouses in the Central Valley of California in 2015 and 2016. Decayed fruit were transported to the laboratory on the same day they were collected, and fungal isolation was attempted. Initial identification of Botrytis spp. was based on the morphological characteristics (Barnett and Hunter 1998). All Botrytis spp. isolates were then single-spored as described previously (Saito et al. 2016b). To confirm the identities of Botrytis isolates, genetic characteristics were examined for all isolates. Genomic DNA for each was extracted as described previously (Saito et al. 2016b) using DNeasy Mini Spin Columns (Qiagen, Valencia, CA) according to the manufacturer's protocol. A PCR restriction fragment length polymorphism based on bchch gene was conducted to separate $B$. cinerea from Botrytis group I (Fournier et al. 2003). Where necessary, a partial gene encoding glyceraldehyde-3-phosphate dehydrogenase (G3PDH), heat-shock protein 60 (HSP60), and DNA-dependent RNA polymerase subunit II (RPB2) were sequenced, and combined dataset of these three genes was used for phylogenetic analysis (Staats et al. 2005). Multiple sequence alignments were performed with Clustal W with the default parameters, and aligned sequences were examined by the maximum-likelihood method in MEGA 7.0 (Kumar et al. 2016). In total, 110 and 201 isolates of $B$. cinerea were obtained from mandarin fruit in 2015 and 2016, respectively.

Fungicides. Four technical-grade fungicides were used for in vitro fungicide resistance tests. Pyrimethanil (98\% a.i.; Bayer CropScience, Research Triangle Park, NC), fludioxonil (93\% a.i.; Syngenta Crop Protection, Greensboro, NC), and thiabendazole (99\% a.i. Sigma-Aldrich, St. Louis, MO) were dissolved in $100 \%$ acetone to prepare stock solutions.

Four formulated fungicides and their concentrations used for the decay control tests were described as follows: PacRite Azoxy 250 $\mathrm{SC}$ at $2.5 \mathrm{ml} /$ liter (22.9\% a.i.; azoxystrobin, Pace International, Wapato, WA); PacRite Penbotec 400SC at $1.25 \mathrm{ml} /$ liter (37.14\% a. i.; pyrimethanil, Pace International); Shield-Brite FDL-230SC at $1.25 \mathrm{ml} /$ liter (20.4\% a.i.; fludioxonil, Pace International); TBZ 500D at $1.25 \mathrm{ml} /$ liter ( $42.3 \%$ a.i.; thiabendazole, Pace International). Silicon super wetter at $10 \mu \mathrm{l} /$ liter (Loveland, Greeley, CO) was added to the fungicide solutions.

Phenotyping fungicide resistance. In total, $200 \mathrm{~B}$. cinerea isolates (100 isolates collected from each of 2015 and 2016) were used for in vitro tests for fungicide resistance.

Resistance to azoxystrobin was determined by detecting the presence of G143A mutation in the cytochrome b gene, which is known to be associated with quinone outside inhibitor (QoI) resistance in many phytopathogenic fungi (Leroux et al. 2010). A partial cytb gene was amplified using the primer pair, Qo13ext and Qo14ext (Leroux et al. 2010). The resulting PCR products were digested with the restriction enzyme Fnu4HI (New England BioLabs, Ipswich, MA) at $37^{\circ} \mathrm{C}$ for $1 \mathrm{~h}$ according to the manufacturer's instructions. Digested products were visualized by electrophoresis in $2 \%$ agarose gels.

Sensitivities to pyrimethanil, fludioxonil, and thiabendazole were determined based on the germ tube elongation method as described previously with slight modifications (Saito et al. 2016b; Weber and Hahn 2011). Fludioxonil and thiabendazole were tested in $1 \%$ malt extract agar (MEA). For pyrimethanil, in order to exclude amino acids from the anilinopyrimidines assay (Myresiotis et al. 2007), $0.5 \%$ sucrose agar (SA) was used instead of MEA. Each medium without the respective fungicide was used as a control.

Conidia from 1- to 2-week-old potato dextrose agar (PDA; Difco Laboratories, Detroit) cultures of $B$. cinerea were used to make inoculum. Cultures growing on 9-cm diameter PDA Petri dishes were flooded with sterile water, and conidia were scraped off the surface of the medium. The resultant conidial suspension was filtered through autoclaved gauze. The conidial concentration was then quantified microscopically with a hemocytometer and diluted to the concentration of $5.0 \times 10^{5}$ spores $/ \mathrm{ml}$. Conidial suspensions were prepared prior to experiment and placed on ice until use. An aliquot of 5- $\mu$ l conidial suspension was streaked out on each plate of the fungicide-amended media or PDA without fungicides, and the plates were incubated at $20^{\circ} \mathrm{C}$ in the dark for 14 to $16 \mathrm{~h}$. Germ tube elongation on each plate was measured under a microscope as previously described (Saito et al. 2016b). All experiments were performed twice.

The discriminatory concentration of each fungicide and the criteria for the classification of fungicide resistant phenotypes were based on previous reports (Saito et al. 2016b; Weber and Hahn 2011). Briefly, two different concentrations for each class of fungicide used in this study were as follows: for pyrimethanil, 1 and $25 \mu \mathrm{g} / \mathrm{ml}$; for fludioxonil, 0.1 and $10 \mu \mathrm{g} / \mathrm{ml}$; and for thiabendazole, 1 and $100 \mu \mathrm{g} / \mathrm{ml}$.

For resistance to pyrimethanil, isolates that showed more than $50 \%$ of growth at $1 \mu \mathrm{g} / \mathrm{ml}$ and no or little growth at $25 \mu \mathrm{g} / \mathrm{ml}$ relative to the control were classified as resistant $(\mathrm{R})$, while sensitive isolates grew less than $50 \%$ at $1 \mu \mathrm{g} / \mathrm{ml}$. For fludioxonil, isolates that grew more than $50 \%$ at $0.1 \mu \mathrm{g} / \mathrm{ml}$ and almost no growth at $10 \mu \mathrm{g} / \mathrm{ml}$ were classified as resistant, while sensitive isolates showed no or little growth at $0.1 \mu \mathrm{g} / \mathrm{ml}$. For thiabendazole, isolates that showed more than $50 \%$ of growth at 1 and $100 \mu \mathrm{g} / \mathrm{ml}$ were classified as resistant, while sensitive isolates showed less than $50 \%$ of growth at $1 \mu \mathrm{g} / \mathrm{ml}$.

Fungicide activities on mandarin fruit inoculated with various fungicide-resistant phenotypes. Five $B$. cinerea isolates with different fungicide-resistant phenotypes were used to determine their effects on control of gray mold with four postharvest fungicides: azoxystrobin, pyrimethanil, fludioxonil, and thiabendazole. Freshly harvested mandarin fruit (cv. W. Murcott) that were not treated with any postharvest treatments were obtained from a local fruit packinghouse and used for the tests. Prior to the experiments, fruit were dipped into $0.5 \%$ sodium hypochlorite for $2 \mathrm{~min}$, rinsed with sterile water three times, and allowed to air dry. A wound $(4.8 \mathrm{~mm}$ in diameter and $7 \mathrm{~mm}$ in depth) was made on the equator side of the fruit. Each $B$. cinerea isolate was cultured on three PDA plates, and three conidial solutions were prepared for each isolate as described above. Conidial suspension was prepared as described above. Conidial suspension obtained from each plate was considered as one replicate for the same isolate. An aliquot of $5 \mu \mathrm{l}$ conidial suspension of the isolate was pipetted into the wound. Nine fruit were inoculated for each of the three replicates, and a total of 27 fruit were placed in a rectangular plastic strainer. The strainer was gently dipped in the fungicide solution at the concentration described above for $30 \mathrm{~s}$, and the strainer was placed on the rack allowing fruit to air dry before packing. Fungicide treated fruit were then placed into a plastic fruit tray. Another plastic fruit tray was placed upside-down on the tray, and a paper towel saturated with sterile distilled water was placed on the top to establish high relative humidity. The fruit trays were placed in a wooden crate and packed in a plastic garbage bag, and then another wooden crate was placed as a lid. The fruit crates were incubated in the dark in a cold room at $5^{\circ} \mathrm{C}$ for 2 weeks. After incubation, disease incidence was recorded, and lesion size was measured in two perpendicular directions. All experiments were performed twice.

Statistical analysis. All statistical analyses were conducted using SAS (version 9.4; SAS Institute, Inc., Cary, NC). The percentage data from the control tests were arcsine-square root transformed prior to analysis. Analysis of variance using PROC GLM in SAS was performed to determine if the data across the runs of each experiment could be pooled. The test indicated that there were no interactions between runs and variables $(P>0.05)$, and thus all data were pooled and further analyzed using PROC GLM. Mean separations were made by Waller-Duncan $K$-ratio $t$ test.

\section{Results}

Fungicide resistance profiles. The presence of the G143A point mutation in the $c y t b$ gene was examined in all $B$. cinerea isolates. Of the $311 \mathrm{~B}$. cinerea isolates examined, the point mutation was detected in $83.6 \%$ (92 out of 110) and $97.5 \%$ (196 out of 201) of the isolates in 2015 and 2016, respectively.

Of the 200 isolates tested for resistance to pyrimethanil, fludioxonil, and thiabendazole, 71 and $93 \%$ of the isolates were resistant to pyrimethanil and 63 and $68 \%$ of the isolates were resistant to thiabendazole 
in 2015 and 2016, respectively (Table 1). Resistance to fludioxonil was not observed (Table 1). Five fungicide-resistance phenotypes were detected with triple resistance to azoxystrobin, pyrimethanil, and thiabendazole being the most prevalent fungicide-resistant phenotype, accounting for 59 and $65 \%$ of isolates in 2015 and 2016, respectively (Table 1). Frequencies of phenotypes resistant to one, two, and three fungicides were $5,23.5$, and $62 \%$, respectively, while that of the isolates sensitive to all four fungicides was $9.5 \%$ (Table 1).

Efficacy of fungicides on mandarin fruit. Pyrimethanil, fludioxonil, and thiabendazole significantly reduced gray mold incidence and severity on the fruit inoculated with isolates sensitive to respective fungicide (Table 2). Although azoxystrobin significantly reduced lesion size on the fruit inoculated with azoxystrobin-sensitive isolate X2305 and even one resistant isolate X1979, all fruit treated with azoxystrobin showed $100 \%$ disease incidence (Table 2). Pyrimethanil significantly reduced lesion size but did not reduce decay incidence on the fruit inoculated with pyrimethanil-resistant isolates, X2835 and X2195 (Table 1). Fludioxonil significantly reduced lesion size and disease incidence on the fruit inoculated with each of the five isolates (Table 2). Thiabendazole effectively controlled thiabendazole sensitive isolates, X2305, X1979, and X2835, but had no effect on thiabendazoleresistant isolates, X2878 and X2195 (Table 2).

\section{Discussion}

In the present study, we reported the presence of various multifungicide resistant phenotypes in the $B$. cinerea population from mandarins, though fungicides are not commonly used in citrus groves in the Central Valley of California. Although several fungicides are commercially available for use as postharvest treatments on citrus in California, the primary targets of these fungicide treatments are green mold, blue mold, and sour rot. As gray mold has become an emerging fruit rot disease of stored mandarin fruit, postharvest decay-control programs for mandarins should also target gray mold in addition to

Table 1. Frequency of fungicide-resistant phenotypes in Botrytis cinerea populations collected from decayed mandarin fruit in 2015 and $2016^{y}$

\begin{tabular}{lcc}
\hline & \multicolumn{2}{c}{ Frequency (\%) } \\
\cline { 2 - 3 } Phenotypes $^{\mathbf{z}}$ & $\mathbf{2 0 1 5}$ & $\mathbf{2 0 1 6}$ \\
\hline $\mathrm{Azo}^{\mathrm{S}} \mathrm{Pym}^{\mathrm{S}} \mathrm{Flu}^{\mathrm{S}} \mathrm{Tbz}^{\mathrm{S}}$ & 17 & 2 \\
$\mathrm{Azo}^{\mathrm{R}} \mathrm{Pym}^{\mathrm{S}} \mathrm{Flu}^{\mathrm{S}} \mathrm{Tbz}^{\mathrm{S}}$ & 8 & 2 \\
$\mathrm{Azo}^{\mathrm{R}} \mathrm{Pym}^{\mathrm{R}} \mathrm{Flu}^{\mathrm{S}} \mathrm{Tbz}^{\mathrm{S}}$ & 12 & 28 \\
$\mathrm{Azo}^{\mathrm{R}} \mathrm{Pym}^{\mathrm{S}} \mathrm{Flu}^{\mathrm{S}} \mathrm{Tbz}^{\mathrm{R}}$ & 4 & 3 \\
$\mathrm{Azo}^{\mathrm{R}} \mathrm{Pym}^{\mathrm{R}} \mathrm{Flu}^{\mathrm{S}} \mathrm{Tbz}^{\mathrm{R}}$ & 59 & 65 \\
\hline
\end{tabular}

${ }^{y}$ In each year, 100 isolates were tested for resistance to the selected fungicides.

${ }^{\text {z }}$ Azo: azoxystrobin, Pym: pyrimethanil, Flu: fludioxonil, Tbz: thiabendazole, S: sensitive, R: resistant. green mold, blue mold, and sour rot. However, fungicide resistance in $B$. cinerea population can result in the failure of disease control. Our findings will be instrumental to the development and implementation of decay-control programs for mandarins that target major postharvest diseases.

Mandarin fruit are grown under a semiarid climate in California, and fungal diseases are in general not major concerns during the fruit growing season. The high frequency of resistance to single or multiple fungicides among the $B$. cinerea isolates obtained from decayed mandarin fruit suggests that the inoculum of fungicide-resistant $B$. cinerea likely comes from fields of other Botrytis-susceptible crops grown in the vicinity adjacent to the mandarin fields because fungicides are not commonly used in citrus groves. In the Central Valley of California, citrus fields are often adjacent to table grape vineyards, blueberry fields, or pistachio orchards where fungicides are commonly used to control various fungal pathogens including $B$. cinerea. Fungicide resistance in $B$. cinerea populations from blueberries and table grapes in the Central Valley of California have been reported (Saito et al. 2016b; Smilanick et al. 2010), and the profiles of fungicideresistant phenotypes from these two crops are very similar to those we reported in the present study, supporting that $B$. cinerea from blueberries and table grapes could serve as sources of fungicideresistant inoculum for citrus grown in the surrounding areas.

The high frequency of multiple-fungicide resistant phenotypes indicated that as multiple fungicides have been used for control of B. cinerea and other diseases, the pathogen has evolved to develop simultaneous resistance to these fungicides. Multiple resistance to chemically unrelated fungicides has also been reported in other crops elsewhere (De Miccolis Angelini et al. 2014; Jurick et al. 2017; Walker et al. 2013; Weber 2011). As multiple fungicide-resistant phenotypes have emerged, control has become more challenging. $B$. cinerea can survive as a saprophyte in the field. Although fungicide sprays may not be intended to target Botrytis diseases, as the fungicides that are effective for control of $B$. cinerea are also commonly used to control other fungal diseases, the nontarget effects of these fungicide sprays on the development of fungicide resistance in $B$. cinerea may have been overlooked. For example, fungicides, such as QoIs, aniliopyrimidines, etc., are commonly used during the growing season up to near harvest to control powdery mildew of table grapes. In table grape vineyards, fungicide sprays for control of powdery mildew may expose $B$. cinerea to selection pressure for development of resistance to the fungicides. Thus, it appears that a season-long fungicide spray program should be implemented not only for disease control but also for management of fungicide resistance in both target and nontarget pathogens.

In the two-year survey, 83 to $97 \%$ of the isolates were resistant to QoIs, indicating widespread QoI resistance in $B$. cinerea populations from mandarins in California. High frequencies of resistance to QoI fungicides in $B$. cinerea populations are now common in many

Table 2. Control of gray mold on mandarin fruit inoculated with five different fungicide-resistant phenotypes of Botrytis cinerea

\begin{tabular}{|c|c|c|c|c|c|c|c|}
\hline \multirow[b]{2}{*}{ Isolate } & \multirow[b]{2}{*}{ Phenotype $^{x}$} & \multirow[b]{2}{*}{ Disease } & \multicolumn{5}{|c|}{ Treatment } \\
\hline & & & Control & Azo & Pym & Flu & Tbz \\
\hline \multirow[t]{2}{*}{$\mathrm{X} 2305$} & 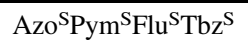 & Severityy & $30.3 \mathrm{a}$ & $18.8 \mathrm{~b}$ & $0.4 \mathrm{~d}$ & $2.6 \mathrm{c}$ & $0.1 \mathrm{~d}$ \\
\hline & & Incidence $^{\mathrm{z}}$ & $100 \mathrm{a}$ & $100 \mathrm{a}$ & $7.4 \mathrm{c}$ & $22.2 \mathrm{~b}$ & $1.9 \mathrm{c}$ \\
\hline \multirow[t]{2}{*}{ X1979 } & $\mathrm{Azo}^{\mathrm{R}} \mathrm{Pym}^{\mathrm{S}} \mathrm{Flu}^{\mathrm{S}} \mathrm{Tbz}^{\mathrm{S}}$ & Severity & $30.1 \mathrm{a}$ & $24.2 \mathrm{~b}$ & $0 \mathrm{~d}$ & $1.2 \mathrm{c}$ & $0 \mathrm{~d}$ \\
\hline & & Incidence & $100 \mathrm{a}$ & $100 \mathrm{a}$ & $0 \mathrm{c}$ & $14.8 \mathrm{~b}$ & $0 \mathrm{c}$ \\
\hline \multirow[t]{2}{*}{ X2835 } & $\mathrm{Azo}^{\mathrm{R}} \mathrm{Pym}^{\mathrm{R}} \mathrm{Flu}^{\mathrm{S}} \mathrm{Tbz}^{\mathrm{S}}$ & Severity & $28.4 \mathrm{a}$ & $29.1 \mathrm{a}$ & $22.2 \mathrm{~b}$ & $0.3 \mathrm{c}$ & $0 \mathrm{c}$ \\
\hline & & Incidence & $100 \mathrm{a}$ & $100 \mathrm{a}$ & $100 \mathrm{a}$ & $3.7 \mathrm{~b}$ & $0 \mathrm{c}$ \\
\hline \multirow[t]{2}{*}{$\mathrm{X} 2878$} & $\mathrm{Azo}^{\mathrm{R}} \mathrm{Pym}^{\mathrm{S}} \mathrm{Flu}^{\mathrm{S}} \mathrm{Tbz}^{\mathrm{R}}$ & Severity & $26.6 \mathrm{a}$ & $27.3 \mathrm{a}$ & $1.4 \mathrm{~b}$ & $0.3 \mathrm{~b}$ & $26.4 \mathrm{a}$ \\
\hline & & Incidence & $100 \mathrm{a}$ & $100 \mathrm{a}$ & $13.0 \mathrm{~b}$ & $3.7 \mathrm{c}$ & $100 \mathrm{a}$ \\
\hline \multirow[t]{2}{*}{ X2195 } & $\mathrm{Azo}^{\mathrm{R}} \mathrm{Pym}^{\mathrm{R}} \mathrm{Flu}^{\mathrm{S}} \mathrm{Tbz}^{\mathrm{R}}$ & Severity & $26.8 \mathrm{~b}$ & $29.0 \mathrm{a}$ & $18.8 \mathrm{c}$ & $2.1 \mathrm{~d}$ & $30.1 \mathrm{a}$ \\
\hline & & Incidence & $100 \mathrm{a}$ & $100 \mathrm{a}$ & $100 \mathrm{a}$ & $20.4 \mathrm{~b}$ & $100 \mathrm{a}$ \\
\hline
\end{tabular}

${ }^{x}$ Azo: azoxystrobin, Pym: pyrimethanil, Flu: fludioxonil, Tbz: thiabendazole, R: resistant, S: sensitive.

${ }^{y}$ Severity was expressed as lesion size $(\mathrm{mm})$ measured in perpendicular directions. Values within the same row followed by the same letter are not significantly different at $K$ ratio $=100(\alpha=0.05)$ according to the Waller-Duncan $t$ test.

${ }^{\mathrm{z}}$ Incidence data $(\%)$ was arcsine-square-root transformed prior to the analysis. Values within the same row followed by the same letter are not significantly different at $K$ ratio $=100(\alpha=0.05)$ according to the Waller-Duncan $t$ test. Data shown in the table are actual percentage. 
different crops worldwide (Leroch et al. 2013; Saito et al. 2016b; Walker et al. 2013). QoIs are high risk fungicides in the development of resistance in fungal pathogens (FRAC 2018). The presence of a high frequency of resistance to QoIs in a pathogen population can also exert selection pressure for development of resistance to other chemistries which are used as a premixture partner. This has been observed in B. cinerea populations from blueberries and Alternaria alternata populations from pistachios (Avenot and Michailides 2007; Saito et al. 2016b).

High frequency of resistance to anilinopyrimidines in $B$. cinerea has also become common on many crops worldwide. For instance, $62.7 \%$ in Chilean vineyards, $14.7 \%$ in small fruit production areas in Germany, 16.9 to $92.6 \%$ in strawberry fields in Italy, and $20.1 \%$ in Californian blueberry fields, were resistant to anilinopyrimidine fungicides, respectively (De Miccolis Angelini et al. 2014; Latorre and Torres 2012; Saito et al. 2016b; Weber 2011). Interestingly, the frequency of resistance to anilinopyrimidines in this study (81\%) was much higher than that of $B$. cinerea isolates collected from blueberry fields in the Central Valley of California (Saito et al. 2016b).

Although fludioxonil resistance has been reported in $B$. cinerea populations from strawberries in the southeastern United States $(\mathrm{Li}$ et al. 2014), in general, fludioxonil resistance has not been detected or at a very low frequency, if detected, in $B$. cinerea populations $(\mathrm{Li}$ et al. 2014; Zhao et al. 2010). In the present study, no fludioxonil resistance was detected among the isolates examined, and our findings are consistent with our previous report that no fludioxonil resistance was detected among $249 \mathrm{~B}$. cinerea isolates collected from blueberry in the Central Valley of California (Saito et al. 2016b). As there was no apparent presence of fludioxonil resistance in the current populations of $B$. cinerea from citrus, and fludioxonil was effective against all fungicide-resistant phenotypes tested on mandarin fruit, fludioxonil appeared to be a viable tool for control of gray mold on mandarin fruit in California. However, an in vitro study demonstrated that $B$. cinerea isolates with dual resistance to thiabendazole and pyrimethanil could rapidly develop resistance to fludioxonil upon consecutive exposure to the fungicide (Jurick et al. 2017). In our study, the phenotype resistant to both pyrimethanil and thiabendazole was prevalent, suggesting that there is a potential risk for development of fludioxonil resistance in the $B$. cinerea populations as fludioxonil is commonly used as Switch (a mixture of fludioxonil and cyprodinil; Syngenta Crop Protection) for gray mold control for blueberries and table grapes in the same region where mandarin fruit are grown. Future monitoring of resistance to fludioxonil in $B$. cinerea populations is of great importance to avoid the development of resistance to fludioxonil.

Although azoxystrobin, fludioxonil, and pyrimethanil were registered more than a decade ago for postharvest use on citrus fruit, the primary targets of these fungicides for citrus were fruit rots caused by Penicillium spp. As gray mold is an emerging postharvest disease of mandarin fruit, postharvest decay-control programs for mandarin fruit should include gray mold and management of fungicide resistance in $B$. cinerea should be implemented. This is the first report of fungicide-resistant profiling in $B$. cinerea from mandarin fruit and the effectiveness of these fungicides for control of gray mold incited by various fungicide-resistant phenotypes. In addition to azoxystrobin, fludioxonil, pyrimethanil, and thiabendazole, two other fungicides, propiconazole and imazalil, belonging to demethylation inhibitors (DMIs), are also labeled for postharvest use on citrus. In the California citrus industry, imazalil and propiconazole are generally used to control green mold and sour rot at citrus packinghouses (McKay et al. 2012; Smilanick et al. 1997). Although according to the manufactures' labels these fungicides do not target gray mold, previous studies suggested possible use of DMIs to control gray mold for grapevine and cucumber (Latorre and Torres 2012; Markoglou and Ziogas 2002). It remains to be evaluated whether these DMIs are effective for control of gray mold incited by various fungicideresistant phenotypes of $B$. cinerea on citrus fruit.

Natamycin has been demonstrated to be effective for control of green mold and blue mold caused by $P$. digitatum and $P$. italicum on citrus fruit (Yigiter et al. 2014). Natamycin was registered in late
2016 for postharvest use on citrus fruit in the U.S. Our preliminary study indicated that natamycin is effective against $B$. cinerea in in vitro tests. As natamycin belongs to a different mode-of-action chemistry than other fungicides commonly used for control of Botrytis diseases, it may have the potential to control gray mold on citrus fruit incited by $B$. cinerea strains that are resistant to those common botryticides. Furthermore, it has been reported that the efficacy of fungicides was improved when used in combination with addition of salts or hot water treatments. For instance, the addition of potassium sorbate or sodium bicarbonate to postharvest fungicides improved their performance in controlling green mold, blue mold, or sour rot on citrus fruit (Smilanick et al. 2006a, b, 2008) and could reduce application rates of the fungicides. Research is currently underway to develop integrated programs to control gray mold on mandarin during storage using available materials that can be readily implemented at citrus packinghouses in California.

\section{Acknowledgments}

We thank J. L. Smilanick, K. Fjeld, K. Fisher, F. Wang, and D. Gautam for technical assistance, and personnel of the citrus packinghouses for assistance in sample collection.

\section{Literature Cited}

Avenot, H. F., and Michailides, T. J. 2007. Resistance to boscalid fungicide in Alternaria alternata isolates from pistachio in California. Plant Dis. 91: 1345-1350.

Barnett, H. L., and Hunter, B. B. 1998. Illustrated Genera of imperfect fungi, 4th Ed. American Phytopathological Society, St. Paul, MN.

Brent, K. J., and Hollomon, D. W. 1998. Fungicide resistance: the assessment of risk. FRAC Monogr. No. 2, Brussels, Belgium.

De Miccolis Angelini, R. M., Rotalo, C., Masiello, M., Gerin, D., Pollastro, S., and Faretra, F. 2014. Occurrence of fungicide resistance in populations of Botryotinia fuckeliana (Botrytis cinerea) on table grape and strawberry in southern Italy. Pest Manag. Sci. 70:1785-1796.

Fournier, E., Levis, C., Fortini, D., Leroux, P., Giraud, T., and Brygoo, Y. 2003 Characterization of Bc-hch, the Botrytis cinerea homolog of the Neurospora crassa het-c vegetative incompatibility locus and its use as a population marker. Mycologia 95:251-261.

Fungicide Resistance Action Committee. 2018. FRAC Code List 2018: Fungicides sorted by mode of action (including FRAC Code numbering). FRAC, CropLife International A.I.S.B.L., Brussels, Belgium.

Holmes, G. J., and Eckert, J. W. 1999. Sensitivity of Penicillium digitatum and $P$. italicum to postharvest citrus fungicides in California. Phytopathology 89: 716-721.

Jurick, W. M., II, Macarisin, O., Gakins, V. L., Park, E., Yu, J., Janisiewics, W., and Peter, K. A. 2017. Characterization of postharvest fungicide-resistant Botrytis cinerea isolates from commercially stored apple fruit. Phytopathology 107: 362-368.

Kanetis, L., Förster, H., and Adaskaveg, J. E. 2008. Baseline sensitivities for new postharvest fungicides against Penicillium spp. on citrus and multiple resistance evaluations in $P$. digitatum. Plant Dis. 92:301-310.

Kumar, S., Stecher, G., and Tamura, K. 2016. MEGA7: Molecular evolutionary genetics analysis version 7.0 for bigger datasets. Mol. Biol. Evol. 33:1870-1874.

Latorre, B. A., and Torres, R. 2012. Prevalence of isolates of Botrytis cinerea resistant to multiple fungicides in Chilean vineyards. Crop Prot. 40:49-52.

Leroch, M., Plesken, C., Weber, R. W. S., Kauff, F., Scalliet, G., and Hahn, M. 2013. Gray mold populations in German strawberry fields are resistant to multiple fungicides and dominated by a novel clade closely related to Botrytis cinerea. Appl. Environ. Microbiol. 79:159-167.

Leroux, P., Gredt, M., Leroch, M., and Walker, A.-S. 2010. Exploring mechanisms of resistance to respiratory inhibitors in field strains of Botrytis cinerea, the causal agent of gray mold. Appl. Environ. Microbiol. 76:6615-6630.

Li, X., Fernandez-Ortuño, D., Grabke, A., and Schnabel, G. 2014. Resistance to fludioxonil in Botrytis cinerea isolates from blackberry and strawberry. Plant Dis. 104:724-732.

Markoglou, A. S., and Ziogas, B. N. 2002. SBI-fungicides: fungicidal effectiveness and resistance in Botrytis cinerea. Phytopathol. Mediterr. 41:120-130.

McKay, A. H., Förster, H., and Adaskaveg, J. E. 2012. Efficacy and application strategies for propiconazole as a new postharvest fungicide for managing sour rot and green mold of citrus fruit. Plant Dis. 96:235-242.

Myresiotis, C. K., Karaoglanidis, G. S., and Tzavella-Klonari, K. 2007. Resistance of Botrytis cinerea isolates from vegetable crops to anilinopyrimidines, phenylpyrroles, hydroxianilide, benzimidazole, and dicarboximide fungicides. Plant Dis. 91:407-413.

Saito, S., Margosan, D., Michailides, T. J., and Xiao, C. L. 2016a. Botrytis californica, a new cryptic species in the $B$. cinerea species complex causing gray mold in blueberries and table grapes. Mycologia 108:330-343.

Saito, S., Michailides, T. J., and Xiao, C. L. 2014. First report of Botrytis pseudocinerea causing gray mold on blueberry in North America. Plant Dis. 98:1743. 
Saito, S., Michailides, T. J., and Xiao, C. L. 2016b. Fungicide resistance profiling in Botrytis cinerea populations from blueberry in California and Washington and their impact on control of gray mold. Plant Dis. 100:2087-2093.

Saito, S., and Xiao, C. L. 2017. Prevalence of postharvest diseases of mandarin fruit in California. Plant Health Prog. 18:204-210.

Smilanick, J. L., Gabler, F. M., Margosan, D. A., and Hashim-Buckey, J. 2010. Control of postharvest gray mold of table grapes in the San Joaquin Valley of California by fungicides applied during the growing season. Plant Dis. 94: 250-257.

Smilanick, J. L., and Mansour, M. F. 2007. Influence of temperature and humidity on survival of Penicillium digitatum and Geotrichum citri-aurantii. Plant Dis. 91:990-996.

Smilanick, J. L., Mansour, M. F., Gabler, F. M., and Goodwine, W. R. 2006a. The effectiveness of pyrimethanil to inhibit germination of Penicillium digitatum and to control citrus green mold after harvest. Postharvest Biol. Technol. 42: 75-85.

Smilanick, J. L., Mansour, M. F., Gabler, F. M., and Sorenson, D. 2008. Control of citrus postharvest green mold and sour rot by potassium sorbate combined with heat and fungicides. Postharvest Biol. Technol. 47:226-238.

Smilanick, J. L., Mansour, M. F., and Sorenson, D. 2006b. Pre- and postharvest treatments to control green mold of citrus fruit during ethylene degreening. Plant Dis. 90:89-96.

Smilanick, J. L., Michael, I. F., Mansour, M. F., Mackey, B. E., Margosan, D. A., Flores, D., and Weist, C. F. 1997. Improved control of green mold of citrus with imazalil in warm water compared with its use in wax. Plant Dis. 81:1299-1304.
Staats, M., van Baarlen, P., and van Kan, J. A. L. 2005. Molecular phylogeny of the plant pathogenic genus Botrytis and the evolution of the host specificity. Mol Biol. Evol. 22:333-346.

USDA-NASS. 2017. Citrus Fruits 2017 Summary. USDA-National Agricultural Statistics Service, Washington, DC. http://usda.mannlib.cornell.edu/usda/ nass/CitrFrui/2010s/2017/CitrFrui-08-31-2017.pdf

Walker, A.-S., Micoud, A., Rémuson, F., Grosman, J., Gredt, M., and Leroux, P. 2013. French vineyards provide information that opens ways for effective resistance management of Botrytis cinerea (grey mould). Pest Manag. Sci. 69:667-678.

Webber, H. J., Barker, R., and Ferguson, L. 2014. History and development of the California citrus industry. Pages 3-20 in: Citrus Production Manual. L. Ferguson and E. E. Grafton-Cardwell, eds. Agric. and Nat. Resources Publ. 3539, Univ. of Calif., Oakland, CA.

Weber, R. W. S. 2011. Resistance of Botrytis cinerea to multiple fungicides in Northern German small-fruit production. Plant Dis. 95:1263-1269.

Weber, R. W. S., and Hahn, M. 2011. A rapid and simple method for determining fungicide resistance in Botrytis. J. Plant Dis. Prot. 118:17-25.

Yigiter, B., Onay, F., Akgul, N. B., and Akocak, P. B. 2014. Natamycin treatment to control postharvest mold development and improve storability of citrus fruits. J. Food Agric. Environ. 12:188-192.

Zhao, H., Kim, Y. K., Huang, L., and Xiao, C. L. 2010. Resistance to thiabendazole and baseline sensitivity to fludioxonil and pyrimethanil in Botrytis cinerea populations from apple and pear in Washington State Postharvest Biol. Technol. 56:12-18. 